\title{
Metal External Ventricular Drainage Catheters in the Treatment of Persistent Ventriculitis - An Old Story Made New: Technical Note and Preliminary Results
}

\author{
Persistan Ventrikülit Tedavisinde Metal Eksternal Drenaj Kateterleri - \\ Eski Bir Hikaye Yeniden: Teknik Not ve Ön Sonuçlar
}

Theodossios BIRBILIS, Georgios MATIS, Olga CHRYSOU, Eleni KARAKOSTA, Demetrios THEMELIDIS, Maria PANOPOULOU

Democritus University of Thrace Medical School, Department of Neurosurgery, Alexandroupolis, Greece

Corresponding Author: Georgios MATIS / E-mail: gkmatis@yahoo.gr

\begin{abstract}
AIM: Conventional ventricular catheters have proven to be ineffective in the drainage of the cerebrospinal fluid in the long run in terms of infection rates. Consequently, the development and clinical evaluation of new catheters is urgently needed.

MATERIAL and METHODS: We implanted a ventricular needle made of stainless steel in 3 neurosurgical patients in whom multiple conventional (silicon) ventricular catheters had been previously implanted. All of them developed persistent ventriculitis during the first 30 days post-admission. The infection did not respond to antibiotics neither intravenously nor intrathecally via conventional catheters. After the implantation of the needle, colistin mesilate sodium was administered (150,000IU/day for 21 days) intrathecally, cerebrospinal fluid white blood cells were measured and cerebrospinal fluid cultures were obtained.

RESULTS: Within 15 days after the implantation of the metal catheter, a significant decrease of the cerebrospinal fluid white blood cell count was noted and all cultures were negative. No operation related complications were observed.

CONCLUSION: Our technique of a metal catheter implantation is safe and requires fewer reoperations. Moreover, it is cost-effective since metal catheters can be used for longer periods of time, can be reused in other patients, and are of low cost.
\end{abstract}

KEYWORDS: Cerebrospinal fluid, Colistin (polymyxin E), External ventricular drain, Metal ventricular catheter, Ventriculitis

Öz

AMAÇ: Geleneksel ventriküler kateterlerin uzun dönemli serebrospinal sıvı drenajında enfeksiyon oranları açısından etkisiz olduğu gösterilmiştir. Bu nedenle yeni kateterlerin geliştirilmesi ve klinik olarak değerlendirilmesi acilen gereklidir.

YÖNTEM ve GEREÇLER: Çok sayıda konvansiyonel (silikon) ventriküler kateterin daha önce implante edilmiş olduğu 3 nöröşirürji hastasında paslanmaz çelikten yapılmış ventriküler bir iğne implante ettik. Tümünde hastaneye yattıktan sonraki 30 günde persistan ventrikülit gelişti. Enfeksiyon konvansiyonel kateterler yoluyla intravenöz veya intratekal antibiyotiklere cevap vermedi. Iğne implantasyonundan sonra intratekal olarak kolistin mesilat sodyum uygulandı (21 gün boyunca 150.000 IU/gün), beyin omurilik sıvısında lökosit sayımı yapıldı ve serebrospinal sıvı kültürleri alındı.

BULGULAR: Metal kateterin implantasyonundan sonra 15 gün içinde beyin omurilik sıvısı lökosit sayımında önemli bir azalma görüldü ve tüm kültürler negatifti. Ameliyatla ilgili herhangi bir komplikasyon gözlenmedi.

SONUÇ: Metal kateter implantasyonu tekniğimiz güvenlidir ve daha az tekrar operasyon gerektirmektedir. Ayrıca metal kateterler daha uzun süre, başka hastalarda da kullanılabilmesi ve maliyeti düşük olması nedeniyle maliyet açısından daha etkin kullanımlıdır.

ANAHTAR SÖZCÜKLER: Beyin omurilik sıvıSı, Kolistin (polimiksin E), Eksternal ventriküler dren, Metal ventriküler kateter, Ventrikülit

\section{INTRODUCTION}

Catheter-associated infection of the cerebrospinal fluid (CSF) is a well-known and eventually devastating complication of external ventricular drainage (EVD) $(2,13)$. The infection rate can be as high as $30 \%$ and increases three-fold more than 18 days after implantation of conventional (silicon) catheters $(23,25)$. Even though it is standard practice to administer antibiotics prophylactically (15), the CSF infection cannot be totally excluded $(13,25)$. On the other hand, the average infection rate of ventriculostomy via metal needles has been reported to be less than $1 \%$ (18).

In order to minimize the risk of ventriculitis several approaches have been proposed both for adults (9, 13, $17,21)$ and children $(20,22,24,25)$; percutaneous needle puncture (25), 'Duisburger Nadel' (10), endoscopic third ventriculostomy alone or combined with choroid plexus 
cauterization (24), antibiotic-impregnated catheters (AIC) $(17,21,22)$, nanoparticles (silver)-impregnated catheters (9, 13) and flexible metal ventricular catheters (23) represent only some of the current practices. In the case of verified ventriculitis the choice of the appropriate catheter to use is far more troublesome.

The scope of this report is to highlight the enhanced therapeutic potential of metal catheters as compared to the conventional (silicon) ones in selected cases of protracted ventriculitis in patients with extended length of stay in an intensive care unit (ICU). To the authors' knowledge there are only 2 articles in the English literature commenting on the superiority of a metal catheter in treating complicated infection of the ventricles $(23,25)$. The efficacy of colistin in eradicating multidrug-resistant bacteria such as Acinetobacter baumannii is additionally underlined $(7,12)$.

\section{MATERIAL and METHODS}

\section{Patients}

Three patients were treated in the Department of Neurosurgery of Democritus University of Thrace, Greece. All of them ( 3 males) were diagnosed with chronic ventriculitis as a result of a prolonged length of stay in the ICU. They had already undergone an average of 6 operations for revision (range: 5-7) with concomitant administration of intravenous and intrathecal antibiotics based on CSF cultures. The isolated bacteria were multidrug-resistant Acinetobacter baumannii and Klebsiella pneumoniae. Yet, this treatment plan did not eradicate the infection. Patient demographics and diseasespecific characteristics are presented in Table I.

\section{Description of the Home-Made Device}

Our home-made device consists of 3 components. The first one is the metal catheter; it is a non-porous stainless steel (AV4) ventricular needle of Cone type with a length of $89 \mathrm{~mm}$ (3.5 inches) and a diameter of 12 Gauge. The needle is composed of 2 lateral wide holes in the distal end, while in the proximal end a Luer Lock hub is found. The second component is a bolt with compression cap, which allows insertion to the desired predefined depth and reliable fixation to the skull. The third component is composed of one safety stop to prevent an accidental catheter migration (Figure 1).

\section{Operative Technique}

One $\mathrm{cm}$ anterior to the coronal suture and $2.5 \mathrm{~cm}$ lateral to the midline on the right side is the location where the burr-hole is made under general anaesthesia (23). If previous attempts on the right side have been made, then the operation is carried out on the left side. The preferred site of implantation is the frontal horn of the right lateral ventricle for two reasons; first, because of the clinically 'silent' frontal lobe and second because of the lack of choroid plexus in this region (eliminating thus the possibility of haemorrhage during the withdrawal of the catheter) (1). The catheter is advanced 6-7 $\mathrm{cm}$ under sterile technique (16). The needle is then fixed to the skull with the aid of a bolt. Standard sutures are used

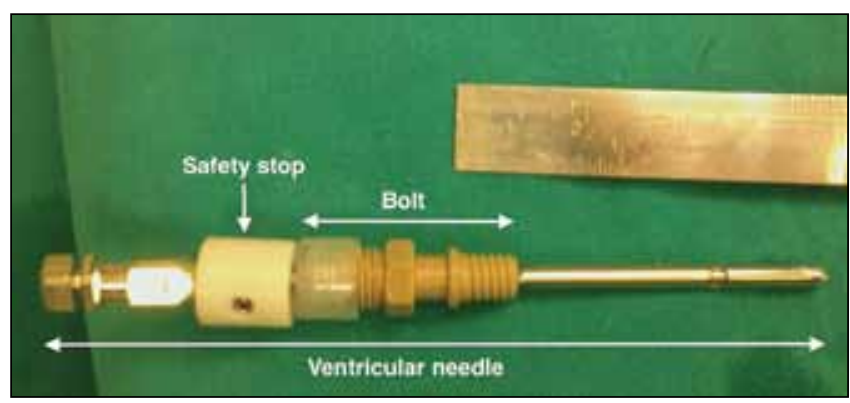

Figure 1: The non-flexible home-made metal external ventricular catheter made of medical stainless steel.

for skin closure. Alternatively, Michel clips are preferred in order to keep the danger of infection low (5). A non-occlusive dressing is applied. The CSF is allowed to drain freely into a graduated flow chamber, which is connected to the EVD catheter via a 3-way stopcock. The whole system is then attached to a collection drainage bag (15). Long-term care includes meticulous site care by a nurse. Topical antiseptics are daily applied to reduce local bacterial skin count around the catheter insertion site (13).

\section{Microbiologic Testing}

Samples of CSF were examined in the Laboratory of Clinical Microbiology of our Hospital for direct examination, Gram stain, and culture. Susceptibility testing was performed by the agar dilution replicate plating method (15). Acinetobacter baumannii isolates were considered susceptible to colistin if the minimum inhibitory concentration (MIC) was $\leq 2 \mathrm{mg} / \mathrm{L}$ and resistant if the MIC was $\geq 4 \mathrm{mg} / \mathrm{L}$ (12).

\section{RESULTS}

Mean operating time for the procedure including fixation and connection to the drainage system was 27 minutes (range 2530). In all three patients $5 \mathrm{mg}=150,000 \mathrm{IU} /$ day Colistin/Norma ${ }^{\circ}$ (polymyxin E) (colistin mesilate sodium 1,000,000 IU/vial, Norma Hellas S.A., Greece) were injected intrathecally via the EVD catheter for 3 weeks (12). This route was chosen due to the poor blood-brain barrier penetration of polymyxins and the nephrotoxicity described via the intravenous administration (14). During this period the CSF white blood cell counts and CSF cultures were followed to assess efficacy. As illustrated in Table I and Figure 2, the decline of CSF cells was obvious even from the $10^{\text {th }}$ post-implantation day. The mean duration of drainage in the 3 patients was 30 days (range 21-40). No intraparenchymal haematomas, no CSF leakage or EVD disconnection were noted.

\section{Case Illustration: Patient 1}

This 56-year-old male presented with subarachnoid haemorrhage (Hunt \& Hess grade 3-4). On admission his Glasgow Coma Scale (GCS) score was 7/15. He had a history of uncontrolled hypertension. The CT and CT-angiography revealed subarachnoid haemorrhage, hydrocephalus, and an aneurysm of the anterior communicating artery. The patient was taken to the operating room, where an EVD was inserted 
Table I: Ventriculitis: Patient Demographics, Primary Diagnosis, CSF Cells Count, Treatment Options, Antibiogram

\begin{tabular}{|c|c|c|c|}
\hline & Patient 1 & Patient 2 & Patient 3 \\
\hline Age (years) & 56 & 62 & 52 \\
\hline Gender & M & M & M \\
\hline Primary diagnosis & $\begin{array}{l}\mathrm{SAH}-\mathrm{IVH}(\mathrm{ACoA} \\
\text { aneurysm rupture) }\end{array}$ & $\begin{array}{l}\text { Intracerebellar } \\
\text { hemorrhage - IVH }\end{array}$ & $\begin{array}{l}\text { SAH - IVH (PCoA } \\
\text { aneurysm rupture) }\end{array}$ \\
\hline Surgical treatment (primary diagnosis) & $\begin{array}{l}\text { Clipping of the ACoA } \\
\text { aneurysm + EVD }\end{array}$ & $\begin{array}{l}\text { Evacuation of the } \\
\text { haematoma + EVD }\end{array}$ & $\begin{array}{l}\text { Clipping of the PCoA } \\
\text { aneurysm + EVD }\end{array}$ \\
\hline Antibiogram & $A B(M D R)$ & $A B+K P(M D R)$ & $A B(M D R)$ \\
\hline Intrathecal treatment (through the MC) & Colistin 150,000 IU/day & Colistin 150,000 IU/day & Colistin 150,000 IU/day \\
\hline Previous or co-administered antibiotics & MER, VAN, GEN & MER, VAN, GEN & MER, VAN, GEN \\
\hline $\begin{array}{l}\text { Nr of CSF cells } 1 \text { day before the implantation of } \\
\text { the } \mathrm{MC}\left(/ \mathrm{mm}^{3}\right)\end{array}$ & 3,530 & 7,500 & 3,560 \\
\hline $\begin{array}{l}\text { Nr of CSF cells } 10 \text { days after the implantation of } \\
\text { the } \mathrm{MC}\left(/ \mathrm{mm}^{3}\right)\end{array}$ & 650 & 440 & 780 \\
\hline $\begin{array}{l}\text { Nr of CSF cells } 21 \text { days after the implantation of } \\
\text { the } \mathrm{MC}\left(/ \mathrm{mm}^{3}\right)\end{array}$ & 11 & 14 & 10 \\
\hline $\begin{array}{l}\text { Nr of CSF cells } 27 \text { days after the implantation of } \\
\text { the } \mathrm{MC}\left(/ \mathrm{mm}^{3}\right)\end{array}$ & 1 & 2 & 1 \\
\hline
\end{tabular}

AC Acinetobacter baumannii; AcoA anterior communicating artery; AVM arteriovenous malformation; CSF cerebrospinal fluid; EVD external ventricular drainage; GEN gentamicin; IU international units; IVH intraventricular hemorrhage; KP Klebsiella pneumoniae; $\boldsymbol{M C}$ metal catheter; $\boldsymbol{M D R}$ multidrug resistant; MER meropenem; $\boldsymbol{N r}$ number; $\mathbf{P C O A}$ posterior communicating artery; $\mathbf{S A H}$ subarachnoid hemorrhage; VAN vancomycin.

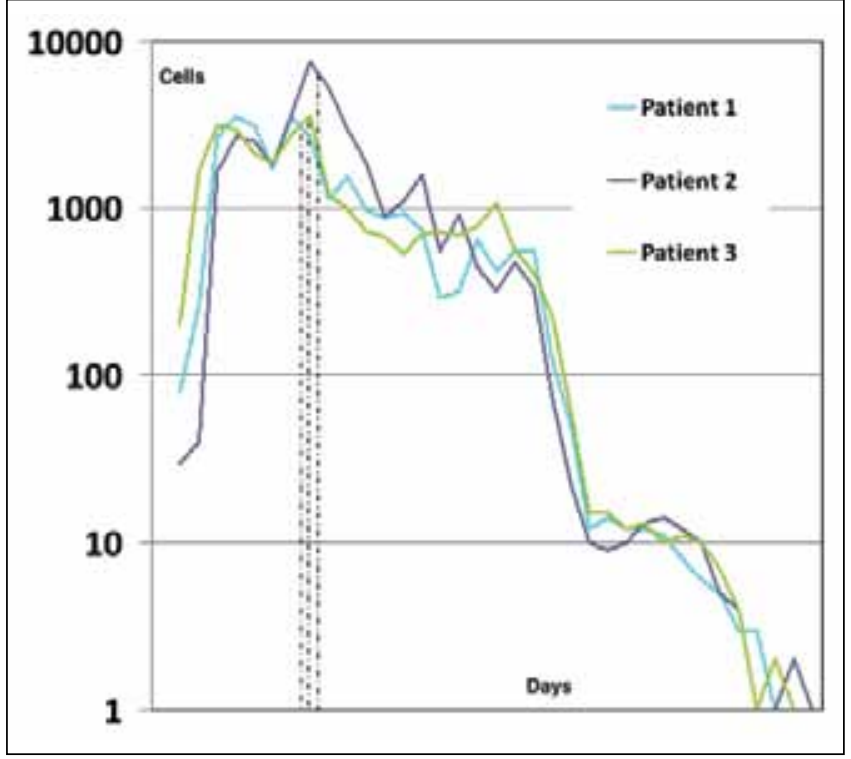

Figure 2: Triple line graph illustrating the drop of the number of cells in the cerebrospinal fluid (CSF) in the 3 patients after the implantation of the metal catheter (dotted vertical lines represent the time of implantation).

and the aneurysm was successfully clipped. Postoperatively his neurological status did not improve and he had to remain in the ICU for 2 months. During these months the EVD catheter was exchanged 5 times to prevent contamination. However, persistent fever and consecutive CSF cell counts suggested infection of the central nervous system which was confirmed by new CT scans (ventriculitis) and positive CSF cultures. At that time appropriate (based on CSF cultures) antibiotics were administered intrathecally and intravenously (meropenem, vancomycin, and gentamicin). In spite of our treatment efforts the cultures remained positive (with additional appearance of Acinetobacter baumannii) and the patient was febrile. The CSF cells reached a maximum number of $3,530 / \mathrm{mm}^{3}$. We then decided to proceed with the insertion of a non-porous metal catheter, which is a well-tolerated material in cases of infection. A new contrast-enhanced cranial CT scan (Figure 3A) showed ependymal enhancement and diffuse brain swelling. Once again the patient was taken to the operating room and a metal catheter was placed on the left side under general anaesthesia (Figure $3 \mathrm{~B}$ ). The drainage system was leveled as shown in Figure 3C. Via this catheter $5 \mathrm{mg}=150,000$ IU/day colistin were injected intrathecally for 3 weeks. At the same time colistin was administered intravenously due to the concurrent diagnosis of pneumonia (also caused by Acinetobacter baumannii) at a dose of $160 \mathrm{mg} / 8 \mathrm{hr}$. Consecutive daily CSF cell counts showed a continuous drop from $650 / \mathrm{mm}^{3}$ (day 10 ) to $11 / \mathrm{mm}^{3}$ (day 21 ) and finally to $1 /$ $\mathrm{mm}^{3}$ (day 27). Twenty-four days after the implantation of the AV4 needle a new CT scan was obtained; the EVD catheter in situ in the left lateral ventricle can be seen in Figure 4. The neurological status of the patient improved progressively $(G C S=10 / 15)$, he had no fever and he was transferred to the Neurosurgical wards. 

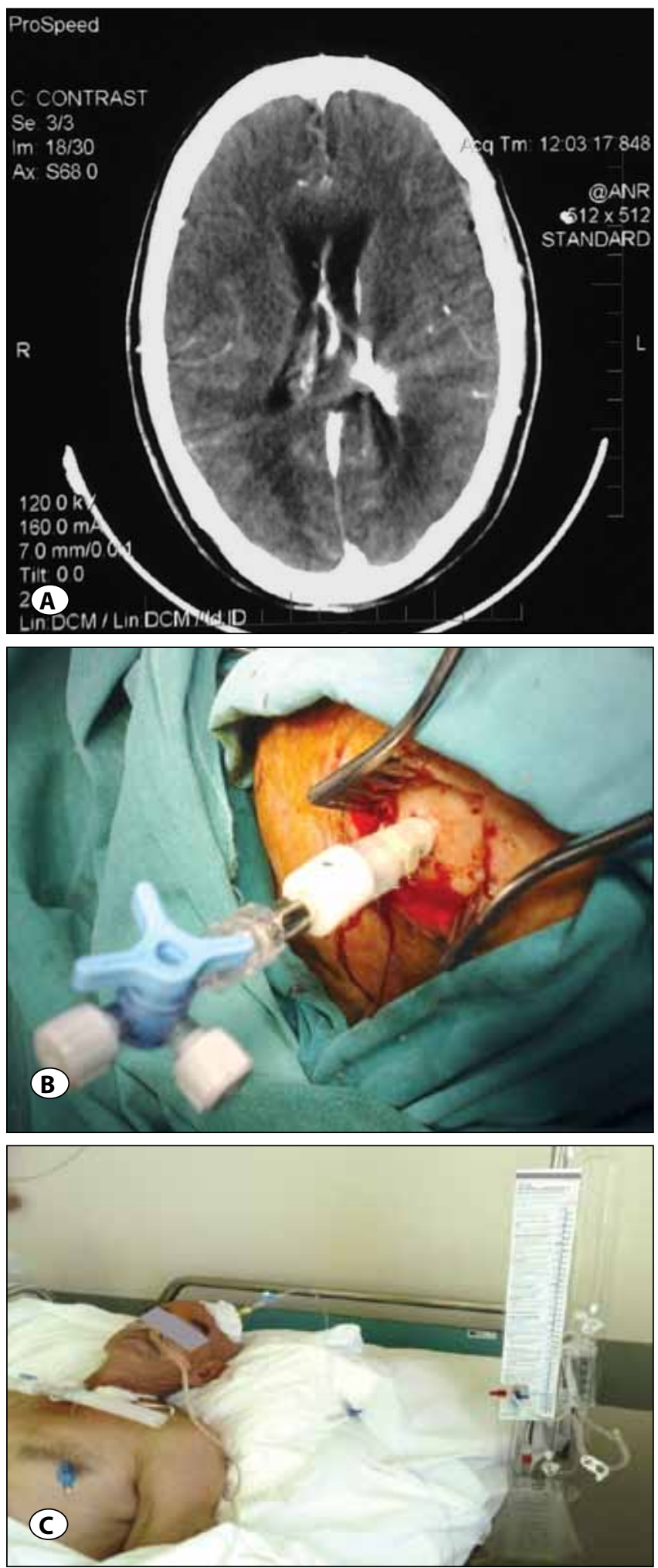

Figure 3: A) CT image (post-contrast) of Patient 1 before the implantation of the metal catheter. B) Intra-operative image. C) Patient 1 in the ward. The tragus of the ear is used as the standard landmark for the external ventricular drainage system level estimation.

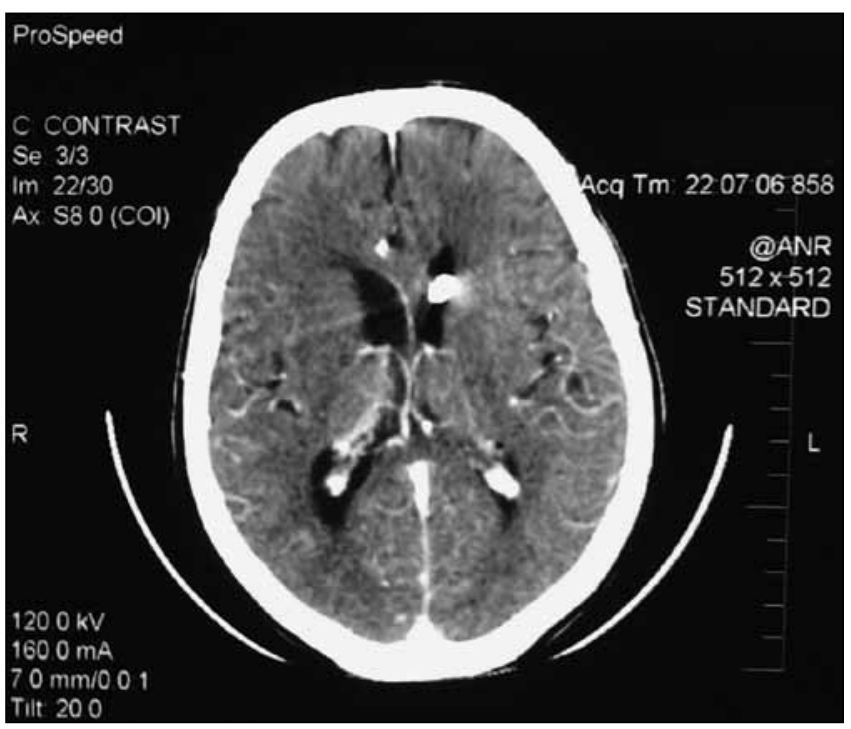

Figure 4: $C T$ image (post-contrast) 24 days after the implantation of the metal catheter.

\section{DISCUSSION}

It is apparent that the diagnostic and therapeutic approach to nosocomial ventriculitis is difficult to standardize (3), especially if one takes into account that the antimicrobial drug resistance rates in many southern European countries are among the highest in Europe (19). Of note, an overadministration of meropenem, vancomycin and gentamicin has been observed in several ICUs, especially after the publication of studies supporting the enhancement of the killing action of meropenem against Pseudomonas aeruginosa and staphylococci by the addition of gentamicin or vancomycin respectively $(4,26)$.

From the microbiological point of view, the preponderance of gram-negative infections raises substantial concern (3). Traditionally, gram-positive microorganisms represented by Staphylococcus aureus and coagulase-negative Staphylococcus species have been the most common pathogens originating from skin flora $(3,15,25)$. On the other hand, pandrugresistant Gram-negative infections are associated with a higher mortality rate, which approaches $58 \%$ in some studies $(8,15)$. Luckily, polymyxin-resistant Pseudomonas aeruginosa, Acinetobacter baumannii and Klebsiella pneumoniae clinical isolates are currently relatively rare (6).

The gram-negative microbial colonization could be attributed to the prolonged hospitalisation of the patients coupled with the policy at our Hospital to administer prophylactic antibiotics before EVD catheters' insertion to protect against skin flora contamination of the wound site but not against gram-negative ones $(2,15)$.

Acinetobacter baumannii was isolated in all 3 patients in this report. This bacterium is typically a health-care-associated pathogen (7). Colistin has been shown to be efficacious as either primary (as in our case) or adjunct treatment of 
multidrug-resistant or pandrug-resistant Acinetobacter baumannii $(7,12)$. It has been reintroduced into clinical practice as a last resort for the treatment of such nosocomial infections with a dosage ranging from $1.6 \mathrm{mg} /$ day to $20 \mathrm{mg} /$ day and duration of treatment ranging from 17 to 56 days (14). The intraventricular use is adequate achieving a cure rate of $100 \%$. The concurrent intravenous administration does not seem to benefit the patient (2). On the contrary, toxicity appears only in those patients who receive additional colistin intravenously $(14,20)$. However, the intravenous administration is indicated and strongly advised whenever additional sites of infection (i.e. lungs, kidneys) are also identified $(3,14)$.

Many devices have been tested over the last 15 years in a continuous effort to address the problem of infection. Antibiotic-impregnated catheters (AIC) seem to be an effective way of reducing the incidence of EVD infections $(21,22)$. In a study of Soleman et al. it was found that time until remission of CSF pleocytosis was significantly longer in patients undergoing EVD with rifampin- and clindamycinimpregnated silicon catheters than in patients who underwent standard EVD. Yet, there was no significant difference between both groups for the time until polymorphonuclear cells dropped below 50\% of peak value, C-Reacting Protein dropped below $10 \mathrm{mg} / \mathrm{l}$, the time of plasma neutrophil remission and hospitalisation time. The data supported only the prophylactic use of AIC for prevention of EVD-related infections (21). A meta-analysis of one randomized controlled trial and three observational studies suggested that AIC reduce the incidence of EVD infections (22). Another study including 75 patients in which 97 EVD were inserted verified the delay of infection in the group of patients treated with AIC (17). However, AIC have raised concerns over bacterial multiresistance (9).

An alternative could be the silver-impregnated EVD catheters. One study addressing the efficacy of such catheters found in 20 control patients 5 catheter-related ventriculitis, while no positive CSF cultures were observed in the treatment group (19 patients) (13). Similar results were published by other authors in a retrospective analysis of 164 patients (9). A possible explanation for this finding could be that silver ions compete with copper ions for cellular entry for certain enzymatic sites at which silver exerts its toxic action (13). Moreover, silver concentrations in the brain tissue were found to be far below accepted levels $(9,11)$.

Endoscopic third ventriculostomy with adjunctive use of choroid plexus cauterisation could be another approach. A study of 179 Ugandan children with post-infectious hydrocephalus due to malaria reported a success rate of $81 \%$ among patients older than 1 year of age. The procedure was successful in 59\% among those patients younger than 1 year of age. The mean follow-up period was 15.2 months (24). Whether this technique could be also applied in adults with ventriculitis in addition to the standard EVD catheter approach remains to be proven.
In the past several studies had focused on the usage of devices made of metal $(10,18,23,25,27)$. In children, a metal needle has been used in the past ('Duisburger Nadel') in emergency situations enabling an immediate and reliable ventriculostomy with a minimal risk of infection (10). Other researchers reported on external CSF drainage by percutaneous metal needle puncture in newborn children (25). The authors implanted a Cytocan port needle with a 20G diameter in 7 infants and no intracerebral haemorrhage or accompanying ventriculitis were encountered. Actually, in two cases a pre-existing ventriculitis was cured by this needle and antibiotic treatment. They also proposed a new needle holder system that could be mounted safely on the thin skull of newborn children (25). Research supports the percutaneous needle implantation for external CSF drainage in adults too, so that the risk of infection can be reduced (18, $23,27)$. Several important drawbacks of drainage needles could be mentioned; first, they are rigid systems. Second, they loosen with time and must be exchanged. Third, they cannot be converted to an internalized shunt. Fourth, their use is not indicated in paediatric patients (23).

A more flexible system was reported in 1996. It was made of implantation steel and consisted of a corrugated tube that rendered it flexible. It was implanted as a temporary and later permanent CSF drainage in 7 males aged from 4 to 60 years. The infection was successfully eliminated in 6 patients. In the $7^{\text {th }}$ patient, the metal catheter had to be removed after 4 days due to a CSF leakage. The average duration of drainage was 27 days. Secondary infection or intracerebral haemorrhage did not occur (23).

Our technique was not associated with any complications such as intracerebral haemorrhages, infections or CSF leakage as noted in various other procedures $(18,23,27)$. The employed device presents three important advantages; first, metal catheters safely stay in the ventricles for a prolonged time period (up to 40 days) presumably due to their non-porous material that renders the bacterial adhesion and colonization limited (23). This is one of the longest implantation durations ever reported. Second, they can be sterilised and thus reused. And third, their financial impact on the budget of Hospitals is negligible.

It is our belief that metal catheters deserve a place in the armamentarium of neurosurgeons and intensivists. Indeed, they could not be the first option for all neurosurgical patients who need an EVD. However, the implantation of such catheters should definitely be considered in specific patient subgroups (extremely poor neurological status on admission, extended length of stay in the ICU, several revisions of conventional ventricular catheters, protracted infections of the CSF pathways that are resistant to treatment with the usual EVD devices, complicated infections, prolonged CSF drainage) (23).

\section{CONCLUSION}

Our technique provides direct access to the ventricular system and satisfactory treatment of ventriculitis in cases where the 
conventional catheters fail. It is easily and safely performed while at the same time requires less reoperations. Last but not least it does not cause a severe financial strain on the health system.

\section{CONFLICTS of INTEREST}

None.

\section{REFERENCES}

1. Baroncini M, Peltier J, Lejeune JP, Le Gars D: Fundamental embryology and anatomy of the lateral ventricle. Neurochirurgie 57:141-150, 2011

2. Beer R, Lackner P, Pfausler B, Schmutzhard: Nosocomial ventriculitis and meningitis in neurocritical care patients. J Neurol 255:1617-1624, 2008

3. Beer R, Pfausler B, Schmutzhard E: Management of nosocomial external ventricular drain-related ventriculomeningitis. Neurocrit Care 10:363-367, 2009

4. Dawis MA, Isenberg HD, France KA, Jenkins SG: In vitro activity of gatifloxacin alone and in combination with cefepime, meropenem, piperacillin and gentamicin against multidrugresistant organisms. J Antimicrob Chemother 51:1203-1211, 2003

5. Doble A, Clark CL, Lumley JS: A comparative study between Michel and Proximate clips for the closure of neck incisions. Ann R Coll Surg Engl 73:204-206, 1991

6. Falagas $M E$, Bliziotis I: Pandrug-resistant Gram-negative bacteria: The dawn of the post-antibiotic era? Int J Antimicrob Agents 29:630-636, 2007

7. Falagas ME, Kasiakou SK: Colistin: The revival of polymyxins for the management of multidrug-resistant gram-negative bacterial infections. Clin Infect Dis 40:1333-1341, 2005

8. Falagas ME, Rafailidis PI, Matthaiou DK, Virtzili S, Nikita D, Michalopoulos A: Pandrug-resistant Klebsiella Pneumoniae, Pseudomonas aeruginosa and Acinetobacter baumannii infections: Characteristics and outcome in 28 patients. Int J Antimicrob Agents 32:450-454, 2008

9. Fichtner J, Güresir E, Seifert V, Raabe A: Efficacy of silver-bearing external ventricular drainage catheters: $A$ retrospective analysis. J Neurosurg 112:840-846, 2010

10. Fundermann $C$, Hans M: Duisburger Nadel - externe Ventrikeldrainage in der Pädiatrie. Z Geburtshilfe Neonatol 211:P31, 2007

11. Galano K, Pleifer $C$, Engelhardt $K$, Brossner G, Lackner P, Huck C, Lass-Flörl C, Obwegeser A: Silver segregation and bacterial growth of intraventricular catheters impregnated with silver nanoparticles in cerebrospinal fluid drainages. Neurol Res 30:285-287, 2008

12. Khawcharoenporn T, Apisarnthanarak A, Mundy LM: Intrathecal colistin for drug resistant Acinetobacter baumannii central nervous system infection: A case series and systematic review. Clin Microbiol Infect 16:888-894, 2010

13. Lackner P, Beer R, Broessner G, Helbok R, Galiano K, Pleifer $C$, Pfausler B, Brenneis C, Huck C, Engelhardt K, Obwegeser AA, Schmutzhard E: Efficacy of silver nanoparticles-impregnated external ventricular drain catheters in patients with acute occlusive hydrocephalus. Neurocrit Care 8:360-365, 2008
14. López-Álvarez B, Martín-Láez R, Fariñas MC, Paternina-Vidal B, Garcia-Palomo JD, Vázquez-Barquero A: Multidrug-resistant Acinetobacter baumannii ventriculitis: Successful treatment with intraventricular colistin. Acta Neurochir 151:1465-1472, 2009

15. Lyke KE, Obasanjo OO, Williams MA, O'Brien M, Chotani R, Perl TM: Ventriculitis complicating use of intraventricular catheters in adult neurosurgical patients. Clin Infect Dis 33:2028-2033, 2001

16. Mapstone TB, Ratcheson RA: Techniques of ventricular puncture. In: Wilkins RH, Rengachary SS (eds), Neurosurgery, Vol 1. New York: MacGraw-Hill, 1985: 151-155

17. McLaughlin N, St-Antoine $\mathrm{P}$, Bojanowski MW: Impact of antibiotic-impregnated catheters on the timing of cerebrospinal fluid infections in non-traumatic subarachnoid hemorrhage. Acta Neurochir 154:761-767, 2012

18. Meyer B, Schaller K, Rohde V, Hassler W: Percutaneous needle trephination. Experience in 200 cases. Acta Neurochir (Wien) 127:232-235, 1994

19. Miyakis S, Pefanis A, Tsakris A: The challenges of antimicrobial drug resistance in Greece. Clin Infect Dis 53:177-184, 2011

20. Paramythiotou E, Karakitsos D, Aggelopoulou $H$, Sioutos $P$, Samonis G, Karabinis A: Post-sugical meningitis due to multiresistant Acinetobacter baumannii. Effective treatment with intravenous and/or intraventricular colistin and therapeutic dilemmas. Med Mal Infect 37:124-125, 2007

21. Soleman J, Marbacher S, Fandino J, Fathi AR: Is the use of antibiotic-impregnated external ventricular drainage beneficial in the management of iatrogenic ventriculitis? Acta Neurochir 154:161-164, 2012

22. Thomas R, Lee S, Patole S, Rao S: Antibiotic-impregnated catheters for the prevention of CSF shunt infections: A systematic review and meta-analysis. $\mathrm{Br} J$ Neurosurg 26: 175-184, 2012

23. Vieweg U, Kaden B, Van Roost D: A flexible metal ventricular catheter for treatment of complicated and protracted infections of the cerebrospinal fluid spaces: Preliminary experiences. Acta Neurochir (Wien) 138:1431-1436, 1996

24. Warf BC: Hydrocephalus in Uganda: The predominance of infectious origin and primary management with endoscopic third ventriculostomy. J Neurosurg 102:1-15, 2005

25. Winking M, Schroth I, Joedicke A, Boeker DK: Technical note: External cerebrospinal fluid (CSF) drainage by percutaneous needle punction in newborn children. Acta Neurochir (Wien) 141:1093-1094, 1999

26. Wise R, Ashby JP, Andrew JM: The antibacterial activity of meropenem in combination with gentamicin or vancomycin. J Antimicrob Chemother 24 Suppl A:233-238, 1989

27. Zentner J, Duffner F, Behrens E: Percutaneous needle trephination for external CSF drainage: Experience in 226 punctures. Neurosurg Rev 18:31-34, 1995 